\title{
REFLEXIONER KRING ÅTERFÖRANDE AV KULTURARV TILL DESS URSPRUNGSPLATS
}

\section{Monika Minnhagen-Alvsten}

Den svenska regeringen och riksdagen har formulerat sin uppfattning om kulturarvet $i$ ett av de kulturpolitiska målen som en fräga om nationell och internationell solidaritet och respekt inför olika gruppers kulturarv. "Kulturarvet i Sverige är ett av mänsklighetens kulturarv och som sädant ett svenskt ansvar gentemot det internationella samfundet. Av motsvarande skäl bör Sverige engagera sig i ett solidariskt samarbete med andra länder för att skydda detta arv".

För naturhistoriska museer gäller andra regler än för de kulturhistoriska. Främst är det Rio-konventionen om bevarande av den biologiska mångfalden och konventionen om handel med utrotningshotade djur som styr.

Ansvarstagandet ska ses i ett brett perspektiv. Det handlar både om att bevara och skydda kulturmiljön, de fysiska lämningarna från olika epoker och om att skydda föremål och andra artefakter.

År 1989 antog FN:s generalförsamling en resolution om återlämnande av kulturföremål. Sverige valde, tillsammans med en rad andra länder, att lägga ner sin röst. Regeringens ståndpunkt är att frågan måste avgöras från fall till fall.

Diskussioner om återförande av föremål till ursprungsplatsen väcker starka känslor som många gånger får sitt uttryck i opinionsbild- ning i massmedia, bildande av stödföreningar etc., men ofta saknas djupare insikter om det historiska perspektivet på hur folkrätten utvecklats och det saknas insikt $i$ hur tidsandan präglat museernas insamlingspolitik och de motiveringar som ligger bakom förvärven.

Jag ska ge några exempel på hur svenska statliga museer löst frågan om återlämnande av föremål. Det finns inga fastslagna riktlinjer och motiveringar och sättet att hantera frågan visar en stor spännvidd.

Krigsbyten är en del i kategorin föremål med utländsk härkomst som väcker diskussion om återförande till ursprungslandet. Krigsbyte kan delas in i två grupper: troféer och krigsbyte. Troféer är militära objekt med anknytning till strid eller belägring. Innehav av troféer betraktas som moraliskt oantastligt. Krigsbyte är andra objekt som förvärvats ge- 
50 nom beslag både för att berika sig själv och för att oskadliggöra fiendens verksamhet.

I allmänhetens ögon kan innehav av krigsbyten uppfattas som orättmätigt och med jämna mellanrum kommer frågan om återlämnande av krigsbyte upp i insändarspalter. Åsikterna är mer präglade av känslor än grundläggande fakta.

Diskussionen har bland annat rört det s.k. Pragrovet från 30-åriga kriget. Sverige var medvetet på jakt efter det kulturellt värdefulla och drottning Kristina skrev till von Königsmarck: "Glöm ej att tillvarata och skicka mig biblioteket". Boksamlingen användes till att bygga upp universitetsutbildningen $\mathrm{i}$ Sverige, men drottningen betraktade också det erövrade som sin privata egendom och tog därför med sig det värdefullaste, när hon lämnade Sverige och flyttade till Rom. I bytet från Prag ingick Djävulsbibeln och i samband med president Havels planerade besök i Sverige 1990 började en upphetsad diskussion i pressen om huruvida Djävulsbibeln skulle lämnas tillbaka. Känslorna svallade på saklighetens bekostnad! En historisk tillbakablick ger en rättvisande och nyanserad bild av situationen.

1500- och 1600-talets syn på krigsbyte skiljer sig markant från dagens. Plundring ingick i avlöningssystemet och medborgarnas egendom representerade enligt tidens synsätt fursten. Plundrade man t.ex. en tysk stad hade man skadat kejsaren. Hugo Grotius, som räknas som den moderna folkrättens grundare, menade i början av 1600-talet att det var helt acceptabelt att både förstöra och röva fiendens egendom. Även Gud ansågs gilla denna inställning som både Sverige och dess fiender omfattade. Det var först under 1700-talet som det växte fram ett modernare betraktelsesätt. Det innebar att krigsbyte betraktades som mindre försvarbart och idag räknas det som krigsförbrytelse.

Diskussionen om återlämnande av Djävulsbibeln blev aldrig en stor fråga bland fackmän. Där var inställningen att krigsbytena ska stanna i landet. Föremålen är inte stöldgods och de har spelat en ovärderlig roll för Sveriges kulturella utveckling. De har funnits här så länge $\mathrm{i}$ landet att de har blivit en del i vårt kulturarv. Genom publikationer, utställningar och Internet är de flesta krigsbytena tillgängliga för forskare världen över oavsett var de är placerade.

Och vem skulle KB återställa Djävulsbibeln till? Ägarlandet, det gamla tyska kejsardömet, finns inte längre.

Visst kan det finnas kulturskatter som upplevs som felplacerade och där man skulle kunna diskutera ett återförande, men det skulle skapa en stor förvirring om man mer generellt började återföra krigsbyten.

Finns några kategorier av föremål med utländsk härkomst bör sändas tillbaka? Diskussionen har pågått inom UNESCO och ICOM och något entydligt svar finns inte. Men det kan vara intressant att titta extra på etnografiska museer. ICOMs International Committee for Museums of Ethnography, ICME, har tagit upp frågan och särskiljer två kategorier där man kan diskutera återförande. Det gäller mänskliga kvarlevor och föremål av religiöst eller symboliskt värde för den etniska grupp som föremålet kommer från. Det finns fyratusen etniska grupper/folk i världen som kan ställa krav och även här måste man diskutera varje särskilt fall.

Ett exempel på hur man kan återföra etnografiskt material med stort symbolvärde från svenska staten till dess hemland är totempålen från Kitlopedalen i Kanada. Den finns på Etnografiska museet i Stockholm, som är stat- 
ligt. Totempålen ingår i museets bassamlingar om nordamerikanska indianer. Den kom till museet per båt 1929 som en donation från Olof Hansson, svensk konsul i British Columbia. Han hade fått köpa den - om än på litet tvivelaktiga grunder - av Haislaindianerna. Den var tillverkad 1872 och återberättar en legend om hövdingen för Kitlopefolket.

Totempålen kan tydligt hänföras till den grupp av föremål som har både religiöst och symboliskt värde för en etnisk grupp. År 1991 uppvaktades Etnografiska museet av representanter för bl.a. Haislaindianerna och Greenpeace. Man önskade att museet skulle lämna tillbaka totempålen till Haisla eftersom den behövdes som symbol och kraftkälla i kampen mot skogsskövlingar i Kitlopedalen.

Etnografiska museet anhöll därför 1992 hos svenska regeringen om att få lämna tillbaka totempålen. Det krävdes regeringsbeslut, eftersom totempålen blev statlig egendom när den infördes i museisamlingen. En allmän debatt följde och många engagerade sig för och emot ett återlämnade. År 1994 beslöt regeringen att totempålen fick återlämnas som "gåva" i samband med det nyligen avslutade urbefolkningens år. Kravet var att museet förvissade sig om att den skulle få en lämplig placering inomhus. Indianerna hade tänk att totempålen skulle sättas upp på ursprunglig plats och enligt traditionen ruttna ner. $\mathrm{Nu}$ högg man istället en kopia som restes på den ursprungliga platsen medan arbetet med att finansiera en byggnad föt originalet inleddes.

Det beslöts också att Sverige skulle få en kopia av totempålen som ersättning, när den ursprungliga återförs. Bildhuggare Henry Robertsson, sonson till den ursprunglige bildhuggaren, ledde arbetet med att tillverka en kopia i museets verkstad år 2000. Men den ursprungliga tomtempålen finns fortfarande kvar trots att det är åtta år sedan beslut om överförande fattades. Varför? Ja, som vanligt är det brist på pengar. Kulturhuset i Kitamaat Village är ännu inte klart!

Återlämnandet av totempålen är ett exempel på hur staten kan hantera ett överförande av statlig egendom. Indianerna får tillbaka sin totempåle i form av en gåva.

Föremål som har återlämnats med hänvisning till ICMEs rekommendationer är kvarlevor av en same som tillbringat 50 år i Statens historiska museum och ett kranium har återbördats till en tasmansk minoritet i Australien. Ett tatuerat huvud har skickats hem till maorierna på Nya Zeeland.

Nordiska museet hanterade återförandet av den norska samling som Artur Hazelius köpt i Norge under 1870-80-talen genom att deponera större delen av föremålssamlingen $\mathrm{i}$ Norsk Folkemuseum. Återlämningsprocessen tog 40 år och periodvis svallade känslorna högt. Två stora frågor dominerade diskussionerna. Skulle samlingen lämnas i sin helhet eller skulle enstaka föremål återföras? Den andra frågan var placeringen. Skulle samlingen stanna på ett ställe eller delas upp geografiskt?

Till skillnad från återlämnandet av totempålen eller diskussionen om återförande av krigsbyten gäller det här inte enstaka föremål med stor symbolisk betydelse. Det handlar om en samling allmogeföremål, som förvärvats helt legitimt och utan imperialistiska förtecken. Frågan om återlämnande är inte sprungen ur folkdjupet. Den väcktes av norska museimän. Samlingen har stort vetenskapligt intresse för förståelsen av norsk folkkonst.

Hazelius tankar om ett nordiskt museum, där han skulle samla och visa minnen från bondesamhället i de nordisk länderna hade sin grogrund i tidens strömningar. Tanken väckte entusiasm. Den norska samlingen blev 


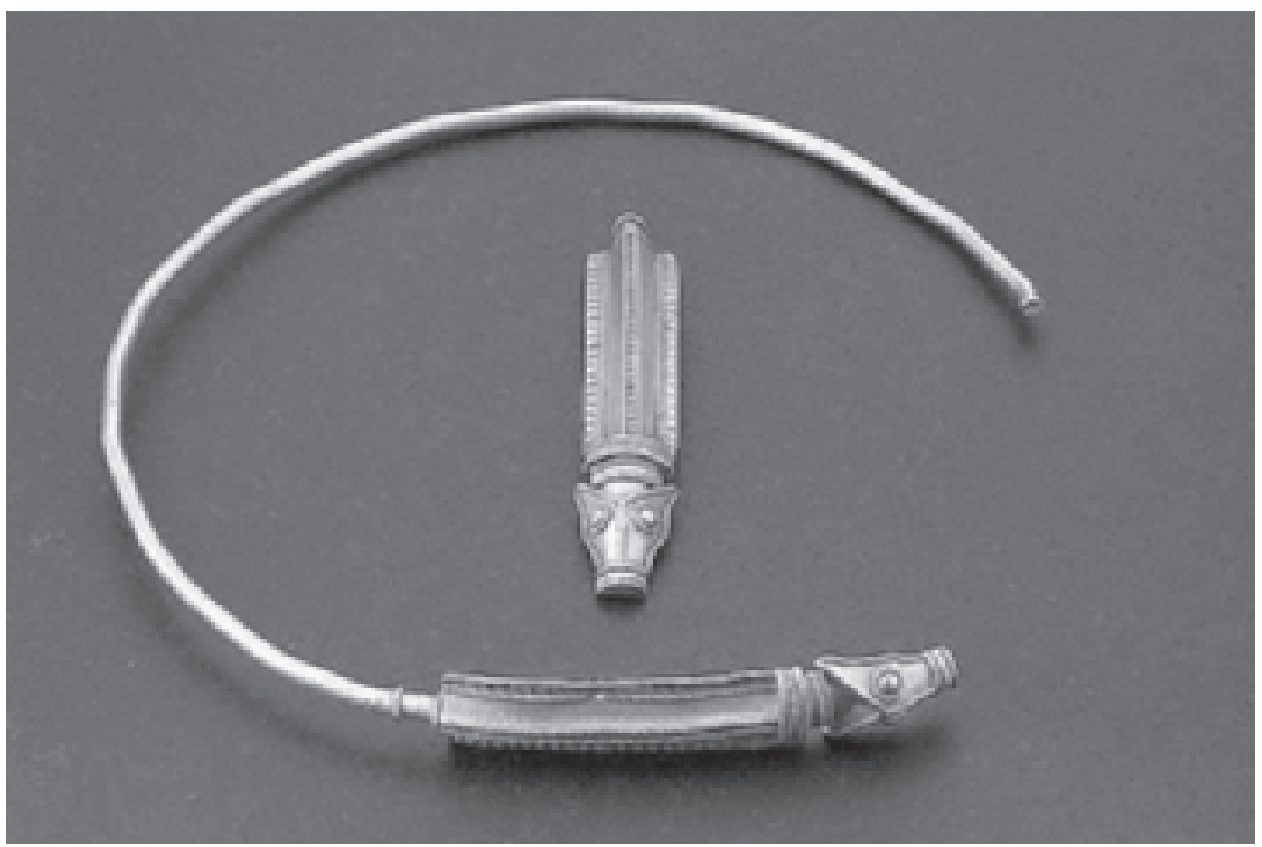

Guldringen frän Nousis, Finland, SHM, Stockholm. Foto: SHM.

den största i Nordiska museet och 1905 vid unionsupplösningen bestod den av 16000 föremål.

Repatrieringsfrågan kom upp under andra världskriget, när många norska museimän arbetade på Nordiska museet. Men åsikterna skar sig på ett par viktiga punkter nämligen om vad som skulle överlämnas. Norrmännen ville plocka russinen ur kakan och ville inte ta emot hela samlingen, vilket var en förutsättning från museets sida. Man hade inte heller berört var i Norge samlingen skulle placeras. Frågan lades på is under hela 1960-talet men väcktes till liv 1972, när styresmannen kontaktade Norsk Folkemuseum för en eventuell deposition. En hätsk debatt utbröt i Norge mellan regionala museer och Norsk Folkemuseum om samlingens placering. Först 1982 kunde Nordiska museet besluta att samlingen skulle överföras till Norsk Folkemuseum. Dessförinnan hade man bett att regeringen skulle yttra sig över konsekvenserna och undersöka om överlämnandet var prejudicerande för återförande av andra museisamlingar. Svaret var nej och 1984 inledes etapp $1 \mathrm{i}$ överflyttningen. Juridiskt löstes frågan om äganderätt genom att samlingen deponerades.

Det är inte alltid som en deposition blir aktuell. Guldringen från Nousis i Finland är ett exempel på en annan typ av lösning på ett önskemål om återförande.

Guldhalsringen hittades 1770 i Finland, då 


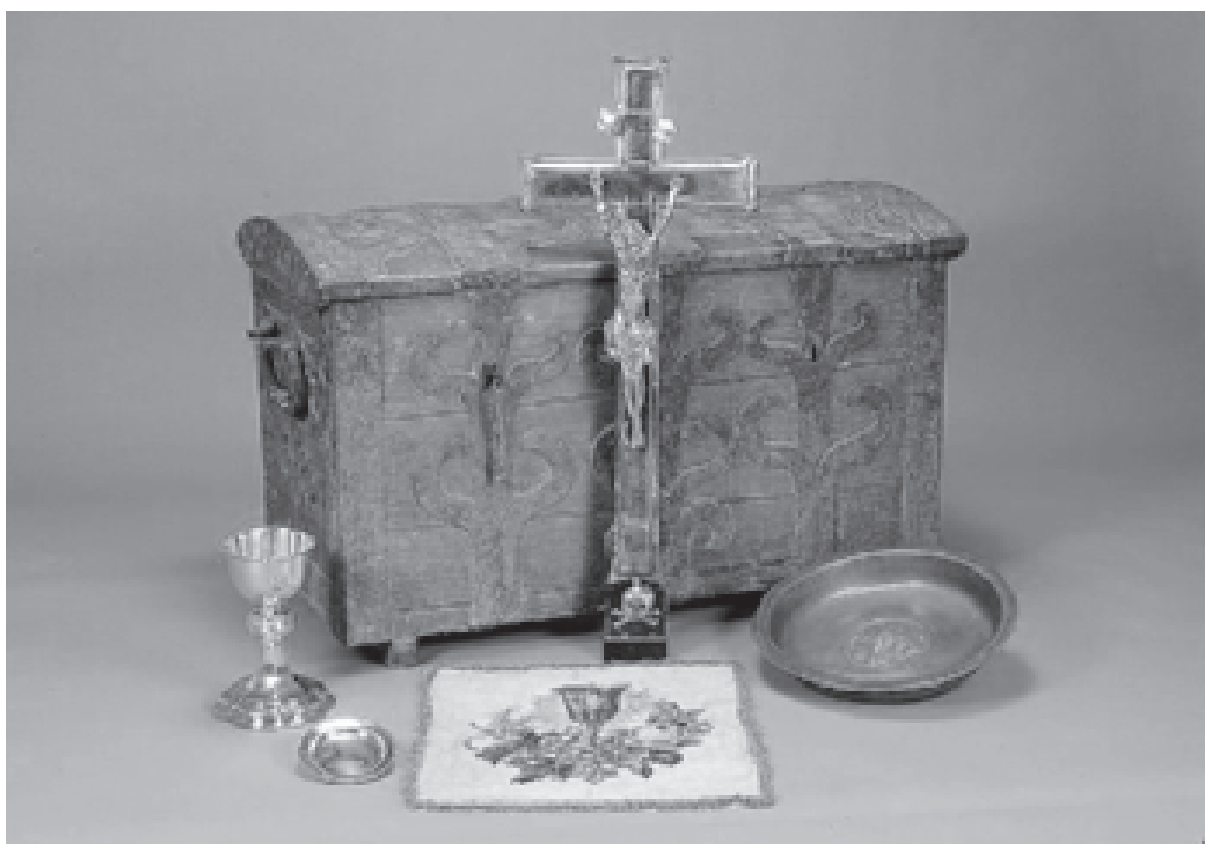

Kyrksilver från S:t Mikaelskyrkan; Tallin. Foto: SHM.

en del av Sverige. Den dateras till 150-200 e.Kr. Halsringen inlöstes till sitt fulla värde enligt 1734 års svenska lag av Kronan och placerades i nuvarande Statens historiska museum i Stockholm. När guldrumsutställningen planerades för ett drygt decennium sedan, kom frågan om återlämnande upp. Man löste problemet genom att tillverka en kopia. Arbetet bekostades av en finsk bank och kopian visas på Nationalmuseum i Helsingfors.

Ett annorlunda exempel på ett kulturarv som är återbördat är det estlandssvenska kulturarvet som förvarats i Sverige sedan andra världskriget. Det var länge en väl bevarad hemlighet att församlingsborna i S:t Mikaels- kyrkan i Tallin tog med sig kyrksilver och inventarier när de flydde till Sverige vid slutet av kriget. Kyrkoherden började packa ner nattvardssilver, altartextilier, krucifix, dopfunt och andra inventarier. Likadant gjorde man på öarna och i kyrkorna efter kusterna, där det fanns estlandssvenska församlingar. Klockaren på Ormsö lyckades packa ner predikstolen. I omgångar tog man sedan inventarierna i flyktingbåtarna över havet. Efter avskedsgudstjänsten inför den sista organiserade resan 1944 tog församlingsborna med sig så mycket de kunde bära. I rädsla för sovjetiska krav på återlämnande förvarades allt under rubriken "Sigurd Curmans deposition" i Historiska museets källare. Riksantikvarie 
54 Curman var den som ledde den kommitté som tog hand om flyktingarna när de steg iland. Fram till 1976 omgavs föremålen med hemlighetsmakeri, men det året ställdes de ut.

$\mathrm{Nu}$ har S:t Mikaelskyrkan, använd som idrottslokal under sovjettiden, renoverats med svenskt bistånd och återinvigdes den 5 maj 2002. Tjugunio föremål hade då återförts. Eftersom samlingen aldrig har varit svenska statens egendom utan en deposition, gick återlämnandet smidigt. Diskussioner pågår med församlingarna på Ormsö, Runö och Rickul om också deras föremål ska lämnas tillbaka.

Även Naturhistoriska Riksmuseet i Stockholm har erfarenhet av önskemål om återlämnande av artefakter. Hanteringen av frågan om återlämnande av fossilen från Bolivia ger en inblick i hur man kan se på frågan om repatriering ur ett forskningsperspektiv. 1998 framförde Bolivias chargé-d'affaires i Stockholm en önskan om att ett antal ryggradsdjur från Tarijaregionen skulle återlämnas. Fossilen var insamlade i början av 1900talet.

Bolivia fick avslag med motivering att den svenska samlingen av fossil från Tarija är en avgränsad samling som har presenterats som en sådan i den vetenskapliga litteraturen, som är omfattande. Det innebar enligt museet att samlingen är tillgänglig för forskare i hela världen. Museet är också mycket generöst med att ge tillstånd till forskare att studera föremålen och det skulle skapa problem för forskarna om samlingen skingrades. Fossilsamlingen har blivit en integrerad del i svensk vetenskapshistoria och förvärvet av fossilsamlingen är helt legalt. Museet påpekade också att det är fullt möjligt för Bolivia att genom utgrävningar i Tarijaregionen få fram fler fossil. Men som en symbol för de goda relatio- nerna mellan Bolivia och Sverige överlämnades en gåva, ett föremål från museets samling, till museet i Tarija.

Låt oss vända blicken mot Sverige och se hur man resonerar inom landet kring förfrågningar om långtidslån från de statliga museerna till regionala museer. Som vi såg i diskussionen kring den norska samlingen i Nordiska museet väcker frågan om det nationella och regionala perspektivet starka känslor.

År 1676 plöjde en bonde ett åkerstycke som tillhörde borgmästaren i det som nu är centrala Linköping och hittade en samling silverföremål som vägde drygt $6 \mathrm{~kg}$. Borgmästaren var inte särskilt benägen att följa 1684 års fyndplacat, som tillerkände kungen och kronan rätten till föremålen, men han fick ge vika: föremålen löstes in av kronan och införlivades i Statens historiska museums samlingar. Skatten är en imponerande samling medeltida föremål av förgyllt silver av stort konstnärligt värde. Samlingen är helt unik. Monstransen och relikvarierna är de enda kvarvarande föremålen av ädelmetall i Sverige från katolsk tid. Det var inte mycket som räddades undan Gustav Vasas giriga fingrar vid reformationen!

I Östgötacorrespondenten skrev chefredaktören i en ledare $\mathrm{i}$ april 2001 att "Kampen med Historiska museet i Stockholm fortsätter för att ge östgötarna en chans att på hemmaplan för njuta av sina historiska föremål”. Hon fortsätter: "...som bekant vill stockholmarna helst att vi alla ska åka dit och beundra skatterna från Gotland, Linköping eller Västergötland”.

Över 7000 östgötar skrev på ett upprop som påtryckning för att få låna ner linköpingsskatten till invigningen av domkyrkomuseet år 2001. Och då gav Historiska museet efter för opinionen och lånade ut den. ”Om det 


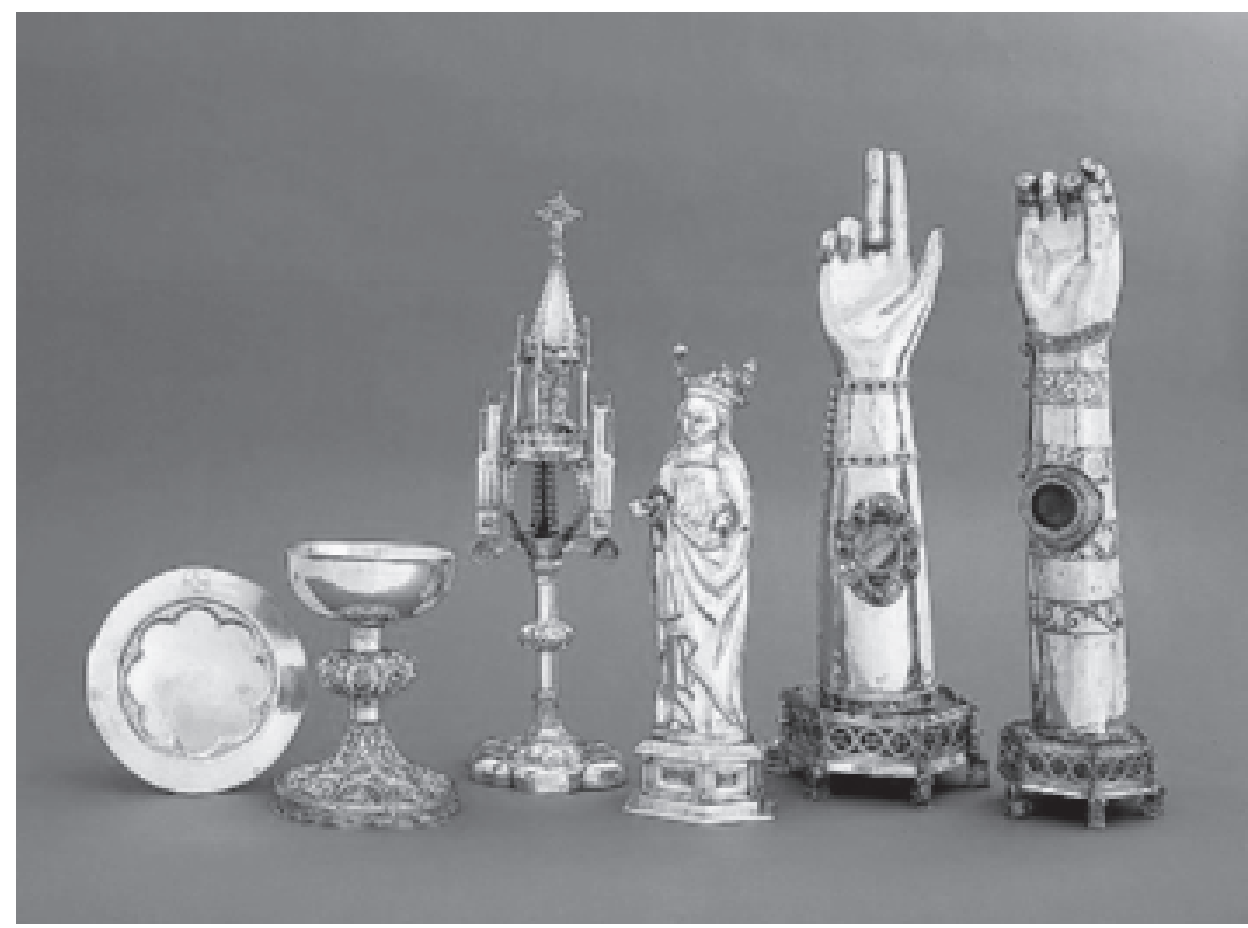

Linköpingsskatten, SHM, Stockholm. Foto: SHM.

blir nödvändigt gör vi om processen”, menar chefredaktören.

Hur ska man se på östgötarnas önskan att stärka sin regionala identitet genom att få visa linköpingsskatten i Domkyrkomuseet? Det flesta villkoren som brukar anges är uppfyllda. Det finns ett modernt domkyrkomuseum som under betryggande former kan visa samlingen. Man vill låna samlingen i sin helhet, inte bara delar. Det behöver inte heller bli aktuellt att ändra ägarförhållandena utan det handlar mer om en välvillig inställning från Statens historiska museums sida till långtidsdepositioner. Problemställningen i fallet med linköpingsskatten är frågan om hur mycket av nationellt värde ska finnas i huvudstaden och hur mycket kan visas på fyndorten? Att det är en fråga som engagerar i dessa tider när kulturturism och regional utveckling står högt på agendan är det ingen tvekan om. I kampen om turisterna blir kulturarvet en viktig ingrediens. Turistnäringen i Östergötland behöver utvecklas för att skapa arbetstillfällen. Linköpingskatten skulle vara ett bra dragplåster. Anledningen till att Historiska museet inte vill låna ut skatten är dels dess nationella symbolvärde och dels risken för att skador uppstår under transporten.

Samma fråga var aktuell för några år sedan i Skåne. Vid den här tiden pågick diskussio- 
ner som bäst om att slå ihop de två Skånelänen för att skapa en stark region som skulle närma sig kontinenten. Man ville frigöra sig från så mycket som möjligt av det statliga inflytandet och låta regionen ta över en stor del av beslutsfattandet.

Den då pågående diskussionen om regionalisering och lokal identitet påverkade Christianstadsbladet att tillsammans med landshövdingen starta en kampanj för att få ner den s.k. Barumskvinnan till länsmuseet i Kristianstad från Statens historiska museum. Barumskvinnan är det äldsta kvinnoskelettet $\mathrm{i}$ landet och hennes symbolvärde var stort, när den skånska historien lyftes fram.

Det började 1939 när Oscar Olsson i Barum, nära Bäckaskogs slott, höll på att gräva en väg ner till Oppmannasjön åt sina kor. Han fann ett skelett. Redan i samband med upptäckten anhöll man från Universitetets Historiska museum i Lund om att skelettet skulle fyndfördelas dit, men det blev avslag. Fyndet flyttades till Statens historiska museum i Stockholm, där det varit utställt sedan 1943. En anhållan från Kristianstad i början av 80talet fick avslag, liksom en senare anhållan.

Barumskvinnan är ytterligare ett exempel på konflikten mellan behovet att av stärka den lokala identiteten och behovet av att hålla det nationella kulturarvet samlat i huvudstaden. Hade länsmuseet överhuvudtaget varit rätta platsen för att visa Barumskvinnan? Hur skulle länsmuseet ha ställt sig till om det hade kommit en anhållan från hembygdsföreningen i Bäckaskog om att få ställa ut skelettet?

Men det händer också att föremål återförs till fyndorten. Statens historiska museum har börjat överföra det arkeologiska fyndmaterialet från medeltidsstaden Lödöse till museet $\mathrm{i}$ Lödöse Det rör sig om 10 000-tals fynd som grävdes fram på 1960-talet och framåt. Här

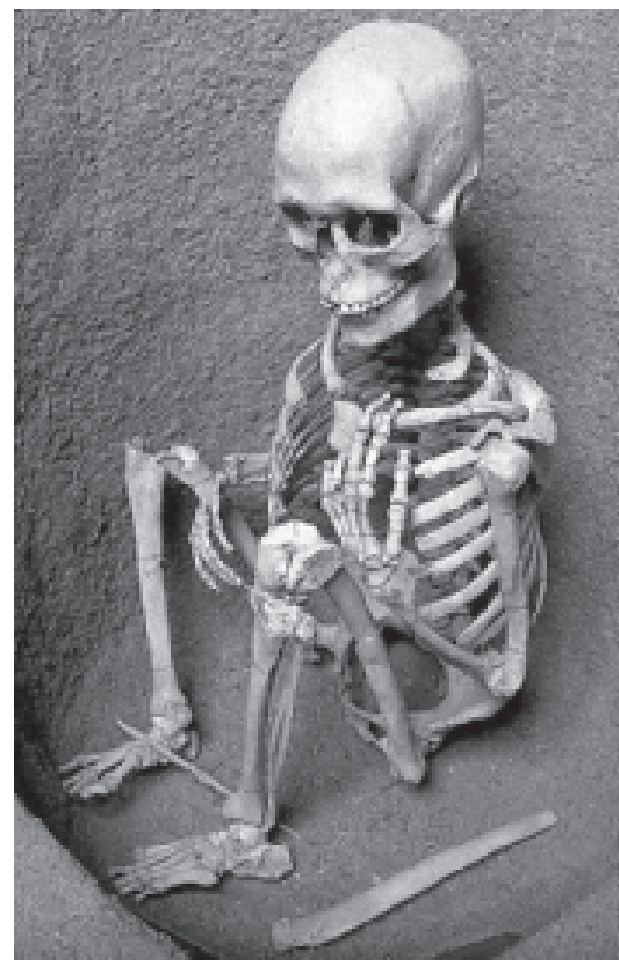

Barumskvinnan. SHM, Stockholm. Foto: SHM.

motiveras återförandet av att en del av fyndmaterialet redan finns i Lödöse och att fynden nu kommer att finnas samlade på ett ställe. "Det betyder mycket för oss att vi nu får tillgång till vårt kulturarv" säger museichefen i en tidningsartikel och han understryker att kulturarvet har en viktig funktion som symbol för identitet och historisk kontinuitet. Forskningsaspekten är viktig. Museet behöver ny kunskap som kan presenteras i utställningar och programverksamhet.

Sammanfattningsvis menar jag att det finns många argument som talar mot att man överlämnar kulturföremål till andra länder. 
Föremål, som befunnit sig länge i svensk ägo och har blivit en del av den svenska bildningshistorien bör stanna i landet, eftersom det skulle skapa stor förvirring för forskningen om åratal av katalogisering och referenser i litteraturen skulle förändras genom ett återbördande. Ur forskningssynpunkt är viktigt att hålla ihop samlingar och med modern informationsteknik har tillgängligheten ökat oavsett var föremålen är fysiskt placerade. En annan aspekt är, att det kan vara svårt att garantera att kraven på god vård och förvaring av föremålen uppfylls.
Det är också många gånger omöjligt att återlämna föremål till den ursprunglige ägaren. Men som framgår av mina exempel går det att göra undantag. Sverige har faktiskt återlämnat föremål genom gåvor, kopior och depositioner.

Avdelningschef Monika Minnhagen-Alvsten, Adr. Riksantikvarieämbetet, Box 5405 , SE-114 84 Stockholm

Fax: +4686607284

E-mail:monika.minnhagen-alvsten@raa.se

\section{NÅGRA SLUTORD...}

- Återförandefrågorna visar tydligt att vi arbetar på två arenor, en offentlig och en inommuseal. Den ena styrs av krafter i samhället som kan tyckas tillfälliga, men som är uttryck för tidsandan. Den andra kan upplevas som tryggare, där vi arbetar med långsiktiga mål samtidigt som vi dock måste ägna våra krafter åt enskilda, ofta små, frågor. I just återförandesammanhanget skymtar museets engagerande och stora betydelse.

- Vi, museimän, vill ladda föremålen med betydelse, men det är viktigt att vi inser att det är andra som tar över tolkningen och utnyttjar våra utsagor. Hur vi förhåller oss till föremålen spelar större roll än vi gärna tror. Vi har sett hur enskilda museimän genom sin person varit helt avgörande för hur återförandefrågor lösts. Det gäller då att vi kan hantera våra egna, djupa känslor

- Vi måste också se oss i samhället och tänka över hur vi kan bidra till samhällsnyttan med det rika kulturarvet i våra händer. Här handlar det om hur vi arbetar strategiskt med politiker och allmänhet, där det kan gälla att rätt hantera de möjligheter till finansiering som uppstår när en fråga hamnat i sökarljuset. När saken inte får uppmärksamhet utan enbart är intermuseal blir läget ett annat.

- Föredragen har understrukit att vi har ett kulturarv, som binder oss samman - alla har vi känt gemenskap med Snorre i Reykholt! Skandinaviska museiförbundet kan lyfta fram och belysa just nordiska övergripande frågor. Ofta kan vi bättre se oss själva genom en nordisk granne som är lik och ändå - olik. Själv har jag genom åren fått mycken inspiration genom det nordiska samarbetet och även fătt pröva hur det håller internationellt.

- I föredragen har framhävts vikten av fortsatt kunskapsutbyte och forskningssamarbete. Det gäller att efter ett återförande vidmakthålla och aktivt arbeta för utbytet. Här kan de två Arnamagneanska instituten vara en förebild. Kulturarvet ägs av alla gemensamt.

Nanna Hermansson, svenska sektionens ordforande 